\title{
PEMBELAJARAN LITERASI INFORMASI TERHADAP MENULIS KARYA ILMIAH SEDERHANA
}

\author{
Vina Merina Br Sianipar \\ Pascasarjana Universitas Negeri Medan \\ Email : vinamerina05@gmail.com
}

\begin{abstract}
ABSTRAK
Literasi informasi adalah seperangkat keterampilan yang diperlukan untuk mencari, menelusur, menganalisis, dan memanfaatkan informasi. Penelitian ini bertujuan 1) untuk mengetahui konsep pembelajaran literasi informasi. 2) untuk mengetahui langkah menulis karya ilmiah sederhana. 3) untuk mengetahui kaitan literasi informasi dalam menulis artikel ilmiah sederhana. Pembelajaran literasi informasi akan mendukung kemampuan siswa dalam menulis karya ilmiah sederhana, sebab memanfaatkan baik dari tekhnologi maupun media cetak sehingga dapat membantu siswa dalam berpikir kritis dan selektif memandang suatu peristiwa. Selain itu dapat membantu siswa dalam mengembangkan kosa katanya.
\end{abstract}

Kata Kunci : Pembelajaran, Literasi Informasi, Menulis Karya Ilmiah Sederhana

\section{PENDAHULUAN}

Pendidikan sangat penting dalam kehidupan manusia. Hal itu diatur sedemikian rupa agar dapat membantu kehidupan manusia. Semua hal dan komponen yang terdapat dalam pendidikan, harus selalu diperhatikan agar mampu menciptakan pendidikan yang bermutu. Pendidikan yang bermutu sangat erat peranannya pada peserta didik dan pendidik. Adanya kerjasama yang baik antara peserta didik dan pendidik mampu menciptakan hasil pembelajaran yang bermutu. Begitu juga segala sesuatu yang dibutuhkan dalam pendidikan baik sarana dan prasarana diatur sedemikian rupa agar tidak terdapat cacat yang membuat pendidikan pada akhirnya tidak sesuai dengan harapan awal.

Pendidikan memiliki banyak hal yang mempengaruhi berhasil tidaknya pendidikan tersebut, salah satunya adalah proses belajar mengajar. Selama ini, salah satu yang dihadapi oleh pendidikan kita adalah lemahnya proses pembelajaran. Sebagian besar pendekatan pendidikan di sekolah-sekolah saat ini berpusat pada guru. Jika ditinjau lebih jauh pada pendekatan tersebut, siswa lebih banyak mendengar, menghapal bahan-bahan yang diberikan oleh guru, dan 
mengulangnya pada waktu ujian. Hal inilah yang mengakibatkan siswa tidak aktif dalam proses pembelajaran. Proses pembelajran yang seperti inilah terkadang kurang memperhatikan perbedaan kemampuan antar siswa. Inilah yang mengakibatkan guru menuntut agar siswa hanya menerima semua materi yang disampaikan dan berhasil dalam ujian tanpa memperhatikan sisi lain kebutuhan siswa.

Setelah diketahui prestasi literasi siswa Indonesia dibandingkan dengan prestasi literasi siswa dari negara-negara lain dan faktor-faktor yang mempengaruhinya, perlu dirumuskan kebijakan dan strategi implementasi yang tepat untuk meningkatkan daya saing dan keunggulan Indonesia. Pendidikan yang berkualitaslah yang mampu menggaransi keberhasilan upaya tersebut. Sebagaimana diamanatkan dalam Undang-Undang Nomor 20 Tahun 2003 tentang Sistem Pendidikan Nasional bahwa pendidikan adalah usaha sadar dan terencana untuk mewujudkan suasana belajar dan proses pembelajaran agar peserta didik secara aktif mengembangkan potensi dirinya untuk memiliki kekuatan spiritual keagamaan, pengendalian diri, kepribadian, kecerdasan, akhlak mulia, serta keterampilan yang diperlukan dirinya, masyarakat, bangsa dan negara.

Sejalan dengan perkembangan ilmu pengetahuan, teknologi, dan seni serta tuntutan perubahan kehidupan lokal, nasional, dan global, akuntabilitas publik terhadap kualitas pendidikan tidak bisa ditawar-tawar lagi. Pembaharuan pendidikan secara terencana, terarah, dan berkesinambungan perlu dilakukan. Pendidikan diharapkan memiliki kesiapan dalam memberikan respon yang positif terhadap berbagai tuntutan kebutuhan masyarakat (Suwandi, 2014: 1), terlebih pada tahun 2015 kita sudah masuk pada Masyarakat Ekonomi ASEAN (MEA) atau ASEAN Economic Community (AEC). MEA menghadapkan kita pada tantangan kompetisi yang lebih besar. Untuk itulah, kualitas praktik dan hasil pendidikan perlu secara terus-menerus ditingkatkan.

Pendidikan merupakan dasar utama menuju jenjang pendidikan yang lebih tinggi, sebab di dalam pendidikan dasar terdapat pengembangan kognitif, afektif dan psikomotorik. Pendidikan juga dibutuhkan proses pembelajaran yang dapat mengembangankan kemampuan siswa, baik dari metode, model dalam pembelajaran. Akan tetapi, zaman sekarang proses pembelajaran lemah sehingga kurang mendorong kemampuan berpikir siswa. Selain itu, siswa juga kurang memiliki keberanian dalam berkomunikasi dengan guru bidang studi di luar jam pembelajaran dalam menanyakan tugas yang diberikan guru. Hal ini tidak hanya luar jam pembelajaran saja, tetapi dalam pemebelajaran juga siswa kurang memiliki keberanian.

Salah satu keterampilan berbahasa yang menuntut daya pikir aktif adalah keterampilan menulis. Menulis adalah suatu bentuk berpikir, tetapi justru berpikir bagi menulis tertentu dan 
bagi waktu tertentu (Tarigan, 2005:22). Dalam pendidikan pembelajaran Literate diperlajari seperti menulis, membaca, berbicara, dan menulis. Khususnya dalam menulis peserta didik memiliki kemampuan tinggi sebab sudah memiliki kata-kata meskipun tidak secara mendalam. Menulis dapat menuangkan semua ide kita ke dalam sebuah tulisan salah satunya artikel.

Kemampuan menulis artikel siswa dapat ditingkatkan dengan menghubungkan Literacy Information dalam pembelajaran. Siswa akan memiliki minat yang tinggi dalam menerapkannya. Hal ini terlihat dari kemajuan teknologi dan komunikasi yang tinggi. Siswa yang cenderung menggunakan teknologi dan informasi akan `menggunakannya untuk mencari materi pembelajaran disekolah seperti halnya menulis artikel. Dimulai dari siswa akan mencari sistematika penulis artikel dan membaca berita dari elektronik maupun media cetak serta melihat kejadian yang dilihatnya.

\section{Literasi Informasi}

Definisi tentang literasi informasi sangat banyak dan terus berkembang sesuai kondisi waktu dan perkembangaan lapangan. Dalam rumusan yang sederhana literasi informasi adalah kemampuan mencari, mengevaluasi dan menggunakan informasi yang dibutuhkan secara efektif. Hakekat dari literasi informasi adalah seperangkat keterampilan yang diperlukan untuk mencari, menelusur,menganalisis, dan memanfaatkan informasi (Bundy, 2001). Mencari informasi dapat dilakukan ke perpustakaan, toko buku, pusatpusat informasi, di Internet dan sebagainya.

Menelusur adalah upaya untuk menemukan kembali informasi yang yang telah disimpan. Jika ke pepustakaan diperlukan alat penelusuran yaitu katalog, sedangkan untuk mencari informasi ke Internet diperlukan search engine. Dalam konteks perpustakaan dan informasi, literasi informasi selalu dikaitkan dengan kemampuan mengakses dan memanfaatkan secara benar sejumlah informasi yang tersedia.

Konsep literasi informasi sebenarnya telah diartikan dan dilakukan dalam berbagai cara sejak awal tahun tujuh puluhan. Semula istilah yang sering digunakan adalah seperti study skills, research skills, dan library skills dan cenderung digunakan dalam konteks kegiatan pendidikan. Oleh karena itu, literasi informasi merukan bagian yang tidak dapat dipisahkan dari kegiatan pendidikan dan/atau pembelajaran. Sedangkan dalam lingkungan kerja sering digunakan istilah information competencies dan information proficiencies. Akan tetapi, apapun istilah yang digunakan, bahwa berbagai istilah ersebut tetap merujuk kepada kemampuan mencari, mengevaluasi, dan menggunakan informasi secara efektif. Kalaupun istilah yang digunakan untuk menyatakan kemampuan ini berbeda-beda, hal itu tergantung kepada lingkungannya. 
Sebagai contoh, sampai dengan pada tahun 1980-an istilah literasi informasi belum begitu dikenal di Indonesia, istilah yang dikenal adalah keterampilan perpustakaan (library skill karena pada masa itu penggunaan sumberdaya informasi elektronik khususnya internet masih langka. Akan tetapi setelah akhir tahun 1990-an penggunaan sumberdaya informasi elektronik khususnya internet di perguruan tinggi sudah membudaya sehingga istilah literasi informasi semakin populer. Terdapat kaitan antara ketersediaan sumberdaya informasi elektronik dengan penggunaan istilah literasi informasi. Dari sisi pandang perpustakaan bahwa pada sejumlah Negara yang tingkat pemerataan fasilitas internetnya sudah merata, maka tingkat literasi informasi penduduknya cenderung merata dan khusus pada perguruan tingggi pelatihan literasi informasi melalui user education telah dapat dilakukan dalam berbagai format dengan memanfaatkan fasilitas internet.

Work Group on Information Literacy dari California State University, mendefinisikan literasi informasi sebagai kemampuan untuk menemukan, mengevaluasi, dan menggunakan informasi dalam berbagai format. Untuk dapat melakukannya maka perncari informasi harus mampu menunjukkan sejumlah keahlian dalam suatu proses yang terpadu, yaitu:

a. Menyatakan pertanyaan, permasalahan, atau isu penelitian.

b. Menentukan informasi yang dibutuhkan untuk pertanyaan, permasalahan, atau isu penelitian.

c. Mengetahui tempat/letak dan menemukan informasi yang relevan.

d. Mengorganisasikan informasi.

e. Menganalisa dan mengevaluasi informasi

f. Mensintesa informasi.

g. Mengkomunikasikan dengan menggunakan berbagai jenis teknologi informasi.

h. Menggunakan perangkat teknologi untuk memperoleh informasi.

i. Memahami etika, hukum, dan isu-isu social politik yang terkait dengan informasi dan teknologi informasi.

j. Menggunakan, mengevaluasi, dan bersifat kritis terhadap informasi yang diterima dari media massa.

k. Menghargai bahwa keahlian yang diperoleh dari kompetensi informasi memungkinkan untuk belajar seumur hidup (California State University, 2002).

Mengutip hasil konklusi yang dibuat oleh Tim dari California State University (2001), bahwa kompetensi literasi informasi bermanfaat bagi kalangan perguruan tinggi karena:

a. Menyediakan metode yang teruji untuk memandu sivitas akademika terutama dosen dan mahasiswa kepada sumber informasi yang terus berkembang. 
b. Mendukung usaha nasional untuk meningkatkan kualitas pendidikan. (hal ini sjalan dengan undang-undang tentang sistem pendidikan nasional pasal 40).

c. Menyediakan perangkat tambahan untuk memperkuat isi perkuliahan.

d. Meningkatkan pembelajaran seumur hidup. Dengan memastikan bahwa setiap indivisu memiliki kemampuan intelektual dalam berpikir secarakritis yang ditunjang dengan kompetensi informasi yang dimilikinya, maka individu dapat melakukan pembelajaran seumur hidup secara mandiri.

\section{Menulis Artikel}

Menurut Kamaroesid (2009:68) menyatakan, "artikel suatu bentuk karangan yang berisi analisis suatu fenomena alam atau sosial dengan maksud untuk menjelaskan siapa, apa, dimana, dan mengapa fenomena alam atau social itu terjadi".

Menurut Hakim (2001:19) menyatakan, bahwa "artikel adalah pemikiran, pendapat, ide dan opini seseorang tentang berbagai tema dan peristiwa". Sedangkan, dalam buku Bambang (2006:4) yang berjudul “ Menulis Artikel Karya Ilmiah" Swarsono menyatakan bahwa "artikel adalah karangan yang menampung gagasan dan opini penulis, bisa berupa gagasan murni atau memungut dari sumber lain, refrensi, perpustakaan, pernyataan orang dan sebagainya”. Dari pernyataan tersebut, dapat disimpulkan bahwa artikel suatu karangan yang membahas suatu masalah yang berdasarkan pemikiran dengan memungut dari sumber lain, refrensi, perpustakan, pernyataan orang.

\section{Jenis Artikel}

Menurut Bambang (2006:10), menyatakan bahwa ada 5 jenis artikel yaitu :

1. Eksploratif

Artikel eksploratif adalah artikel yang mengungkapkan fakta-fakta berdasarkan kajian dari penulisnya. Jenis artikel ini cocoknya untuk menguraikan penemuan-penemuan baru, misalnya seseorang yang menemukan Batu Akik di Sungai.

2. Eksplanatif

Artikel eksplanatif adalah artikel yang menerangkan sesuatu untuk dapat dipahami pembacanya. Misalnya Ketika Presiden Gus Dur ingin membubarkan dekrit presiden. Nah disini, penulis artikel menerangkan apa sih dekrit president.

3. Deskriptif 
Artikel deskriptif adalah artikel yang menggambarkan suatu permasalahan yang terjadi di tengah masyrakat, sehingga dapat mengetahui apa yang sebenarnya terjadi. Misalnya, ketika aparat bentrok dengan mahasiswa dalam peristiwa Semanggi di Jakarta.

4. Prediktif

Artikel prediktif adalah artikel yang berisi perhitungan atau ramalan apa yang bakal terjadi di kemudian hari berdasarkan perhitungan penulisnya. Misalnya, ketika Bank Indonesia memutuskan menaikan suku bunga depositi, seorang pengamat ekonomi akan memperkirakan kelak orang Indonesia akan menyimpan depositonya ke luar negeri.

5. Preskriptif

Artikel preskriptif adalah artikel yang memberikan tuntunan kepada pembacanya untuk melakukan sesuatu sehinga tidak mengalami kekeliruan.

\section{Syarat Artikel Layak Kirim}

Dalam buku Kamaroesid (2009:70) yang berjudul "Bimbingan Praktis Menulis Karya Ilmiah" Sumadiria mengemukan beberapa syarat dalam mengirim artikel yaitu :

1. Topik yang diangkat benar-benar actual atau controversial.

2. Tesis yang diajukan orisinal serta mengandung gagasan baru dan segar.

3. Materi yang dibahas menyangkut kepentingan yang sangat masyarakat luas.

4. Topic atau pokok bahasan yang dikupas diyakini tidak bertentangan dengan aspek etis, yuridis, sosiologis, dan ideologis.

5. Ditulis dalam bahasa baku yang benar dan baik, serta mudah dicerna.

\section{Cara Membuat Artikel}

Menurut Kamaroesid (2009:69) mengemukakan dua macam artikel berdasarkan cara membuatnya yaitu :

1. Artikel yang murni merupakan refleksi dan pendapat dari penulisnya, tanpa bantuan pustaka atau refrensi khusus.

2. Artikel yang diracik penulisnya dengan memakai bantuan pustaka atau refrensi khusus yang dirasa ada kaitannya dengan tema artikelnya yang sedang digarap.

Jika seorang penulis mengutip dan mempergunakan pustaka dan refrensi dalam tulisnnya, maka penulisnya harus mencantumkan sumbernya secara jelas, sebagai pertanggungjawaban intelektual. Jika tidak mencantumkan sumbernya secara jelas, penulis tersebut bisa dituduh sebagai plagiator atau penciplak dan bias dituntut telah melanggar UU Hak Cipta. Sedangkan, dalam buku Kuncoro (2009:70) yang berjudul “ Mahir Menulis Kiat Jitu Menulis Artikel, 
Kolom, dan Resensi Buku" Hermanvarella mengemukakan beberapa langkah menulis artikel yaitu :

1. Menggali ide. Ketika menemukan ide, cobalah analisis masalah tema tersebut.

2. Membuat kerangka tulisan secara rinci. Pastikan kerangka tulisan berstruktur pembukaan, isi, penutup.

3. Kumpulkan data dan refrensi (buku, majalah, Koran, hasil penelian, dan lainnya)

4. Mulailah menulis.

5. Editing. Editing diperlukan untuk mengetahui apakah tulisan kita sesuai dengan Ejaan Yang Disempurnakan dan layak-tidakkah tulisan kita untuk dimuat di media massa.

\section{Kohesi dan Koherensi}

Salah satu kemampuan yang harus dikuasai oleh seseorang yang mengarang dalam bahasa Indonesia adalah menguasai bahasa Indonesia. Penguasaan bahasa Indonesia adalah mengetahui, memahami dan dapat menggunakan kaidah-kaidah bahasa Indonesia dengan baik dan benar. Penggunaan bahasa khusunya dalam menulis harus memperhatikan kohesi dan koherensi di dalam paragraf, agar pembaca dapat memahami maksud penulis. Menurut Keraf (1973:84) menyatakan bahwa "koherensi adalah kepaduan dalam membentuk hubungan timbal balik dalam kalimat supaya mudah dipahami pembaca tanpa mengalami kesulitan." Sitorus (2014: 44) menyatakan bahwa " kohesi adalah keserasian antar paragraph yang ditandai hubungan sebab akibat, baik antar klausa maupun antar kalimat." Penggunaan kohesi dan kohesi dalam menulis sangat dibutuhkan, seperti dalam menulis artikel. Jika dalam paragraf tidak ada kesatupaduan antar paragraph, makna yang terkandung dalam paragraph tidak dapat tersampaikan kepada pembaca. Alinea dapat juga membentuk suatu kesatuan paragraph, walaupun koherensinya tidak ada. Kesatuan paragraph tergantung dari gagasan di seluruh paragraf yang dapat membentuk gagasan utama dan dinyatakan dalam sebuah kalimat topik.

\section{Diksi}

Menurut Aleka dan Achmad (2010: 57) menyatakan bahwa "Diksi adalah gaya bahasa yang disesuaikan dengan pilihan kata di dalam suatu wacana secara efektif. Gaya bahasa mempengaruhi terbentuknya suasana, kesopanan, kemenarikan, dan realita dalam suatu wacana.

Penggunaan diksi mempengaruhi penguasaan bahasa yang terkait dengan kemampuan menggunakan kosa kata secara aktif dan pasif kepada pembaca dan pendengar. Hal ini, dapat 
membuat suatu wacana atau karya tulis memiliki tingkat kesuksesan dalam menulis, karena dalam suatu karya tulis, isi wacana atau karya tulis tidak hanya melihat isinya saja, tetapi rangkaian kata yang ditulis si penulis. Seorang pembaca dapat diketehaui memiliki diksi yang baik atau tidak, dan memiliki diksi yang banyak atau tidak.

\section{Literasi Informasi Dalam Menulis Artikel Ilmiah Sederhana}

Proses pembelajaran menjadi faktor pemicu keberhasilan pembelajaran yang efektif dan efisien. Dengan pesatnya perkembangan di segala bidang tentunya menuntut sistem pembelajaran yang tepat agar siswa secara efektif dan efisien pula mendapatkan pengetahuan yang mengglobal. Hal ini menjadi alasan perlunya pembenahan proses pembelajaran. Pembelajaran di era global harus lebih menekankan penerapan pembelajaran dengan pendekatan kontekstual, aktif dan konstruktivis karena dianggap mampu membentuk karakter pembelajar pada diri peserta didik serta bisa memicu motivasi dan kreatifitas (Fitri Oviyanti, 2013: 285).

Pembelajaran menulis artikel harus konkrti dan padu sebab dapat memberikan efek positif bagi siswa. Pembelajaran menulis artikel semakin efektif dengan menggunakan peran literasi sesuai K-13 yang sudah mulai diterapkan disekolah yaitu GLS ( Gerakan Literasi Sekolah). Akan tetapi, literasi juga harus diketahui guru atau pendidik karena literasi tidak hanya membaca dan menulis tetapi juga harus diketahui jenisnya. Salah satunya yaitu literasi informasi. Disini guru akan mengkaitkan literasi informasi sebagai metode pembelajaran untuk menghubungkan kemampuan siswa diluar sekolah dari segi rutinitas sehari-hari. Melalui literasi informasi, guru dapat memanfaatkan media cetak maupun teknologi sebagai penghubung pemahaman siswa.

Perkembangan zaman menunjukkan siswa tidak lepas dari gadged (HP) sehingga siswa sering online atau update dalam media sosial. Hal inilah dapat menguntungkan guru untuk mengembangkan pemahaman siswa melalui berpikiran kritis terhadap suatu kejadian baik politik dan non politik sehingga siswa terlatih pengembangan kosa kata, pemahaman kritis baik subjektif maupun objektif.

Kemajuan zaman menyebabkan jeda waktu antara pengetahuan baru yang (up to date) dan pengetahuan lama (out of date) sekarang sudah sangat dekat dan cepat sekali. Setiap orang perlu lebih responsif dan adaptabel terhadap perubahan dan perkembangan terutama kelompok masyarakat pendidikan. Beberapa ciri yang bisa dikatakan sebagai manusia yang mudah beradaptasi dan responsif terhadap perkembangan informasi untuk menjadi manusia yang melek informasi perlu memahami langkah sebagai berikut: 
a) Determine the extent of information needed (Menentukan tingkat informasi yang dibutuhkan)

b) Access the needed information effectively and efficiently (Akses informasi yang dibutuhkan secara efektif dan efisien)

c) Evaluate information and its sources critically (Mengevaluasi informasi dan sumbernya kritis)

d) Incorporate selected information into one's knowledge base (Memasukkan informasi yang dipilih ke dalam basis pengetahuan seseorang)

e) Use information effectively to accomplish a specific purpose (Gunakan informasi secara efektif untuk mencapai tujuan tertentu);

f) Understand the economic, legal, and social issues surrounding the use of information, and access and use information ethically and legally (Memahami dari sisi ekonomi, hukum, dan sosial isu seputar penggunaan informasi, dan akses dan menggunakan informasi secara etis dan legal)( American Library Association dalam www.ala.org).

\section{PENUTUP}

Pembelajaran literasi informasi sangat berkaitan dengan kemampuan menulis artikel karena dapat membantu pemahaman siswa lebih mendalam. Hal ini Sejalan dengan perkembangan ilmu pengetahuan, teknologi, dan seni serta tuntutan perubahan kehidupan lokal, nasional, dan global, akuntabilitas publik terhadap kualitas pendidikan tidak bisa ditawar-tawar lagi. Oleh karena itu, kemajuan teknologi akan membantu sikap kritis siswa dalam menulis karya ilmiah sehingga dapat mengembangkan pemikiran siswa lebih baik.

Pembelajaran literasi informasi harus diterapkan dalam semua mata pelajaran khusus terhadap kemampuan menulis karena dapat melatih pemikiran kritis dan peningkatan diksi siswa. Guru harus memiliki trik dan solusi untuk meningkatkan kemampuan pembelajaran siswa dengan mengkaitan literasi, salah satunya literasi informasi. Selain itu, guru juga harus mengetahui jenis-jenis literasi supaya dapat mengaplikasikannya dalam pembelajaran

\section{DAFTAR PUSTAKA}

Aleka dan Achmad. 2010. Bahasa Indonesia untuk Perguruan Tinggi. Jakarta : Kencana

Bambang, dkk. 2006. Menulis Artikel Karya Ilmiah. Jakarta : Gramedia

Hakim, Arif. 2011. Menulis Artikel Di Media Cetak. Jakarta : Gramedia

Hasugian, Jonner. Urgensi Literasi Informasi dalam Kurikulum Berbasis Kompetensi di Perguruan Tinggi. Jurnal Studi Perpustakaan dan Informasi. Vol 4 No. 2. 2008 
Nur, Fauziah. 2015. Upaya Guru Dalam Pengembangan Literasi Informasi Siswa Pada Mata Pelajaran PAI. FKIP UIN SYARIF HIDAYAHTULLAH

Nurohman, Aris. 2014. Signifikan Literasi Informasi dalam Dunia Pendidikan di Era Global. Jurna Kependidikan. Vol II No.1. 2014.

Kamaroesid, Herry. 2009. Bimbingan Praktis Menulis Karya Ilmiah. Jakarta: Referensi

Oviyanti, Fitri. (2013). Tantangan Pengembangan Pendidikan Keguruan di Era Global. Jurnal Nadwa. Volume 7, Nomor 2, Oktober 2013. Hlm. 273-290.

Sitorus, dkk. 2014. Wacana Bahasa Indonesia. Medan: UHN

Suwandi, Sarwiji. 2015. Peran Bahasa Indonesia Dalam Pengembangan Budaya Literasi Untuk Mewujudkan Budaya Yang Unggul Dalam Konteks Masyarakat Ekonomi ASEAN. Prosiding Seminar Nasional Pendidikan Bahasa dan Sastra Indonesia Universitas Sebelas Maret.

Suyono. 2009. Pembelajaran Efektif dan Produktif Berbasis Literasi. Bahasa dan Seni. No. 2 Agustus 2009. Universitas Negeri Malang

Undang-Undang Nomor 20 Tahun 2003 tentang Sistem Pendidikan Nasional 